\title{
Acute presentation of oncologic disease
}

\author{
SE De Luca*, E Casalini Vañek, C Carrera, JE Codas Thompson, MC Wirtz, EP Eyheremendy \\ From International Cancer Imaging Society (ICIS) 14th Annual Teaching Course \\ Heidelberg, Germany. 9-11 October 2014
}

The number of complicated oncologic patients is increasing accordingly to the high overall prevalence of cancer and the improved survival rate due to advances in cancer treatments. Progression disease and treatmentrelated complications are the most common causes. In this presentation, we review the pathophysiology of selected oncologic emergencies in which radiologists play a critical role in timely diagnosis and thus have a significant impact on patients' care.

We selected patients who attended the emergency department of our hospital between 2010 to 2014 with different acute symptoms.

Of the oncological emergencies presented we found most commonly: compression of the spinal cord (4.5\%), carcinomatous meningitis (13.6\%); obstruction of the central airway (9\%), oesophageal fistula (9\%), pulmonary embolism (9\%), superior vena cava syndrome (4.5\%), pelvic abscess (18\%), intra-abdominal haemorrhage (9.5\%) and intestinal intussusception (13.6\%).

Oncologic emergencies represent important causes of death in cancer patients. Radiologists should be familiar with imaging findings of acute conditions to optimize patient care. Recognition of key imaging findings allows prompt diagnosis and facilitates treatment, reducing morbidity and mortality with consequent better outcome.

Submit your next manuscript to BioMed Central and take full advantage of:

- Convenient online submission

- Thorough peer review

- No space constraints or color figure charges

- Immediate publication on acceptance

- Inclusion in PubMed, CAS, Scopus and Google Scholar

- Research which is freely available for redistribution

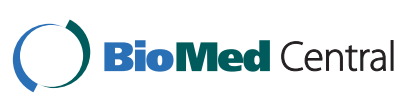

(c) 2014 De Luca et al; licensee BioMed Central Ltd. This is an Open Access article distributed under the terms of the Creative Commons Attribution License (http://creativecommons.org/licenses/by/4.0), which permits unrestricted use, distribution, and reproduction in any medium, provided the original work is properly cited. The Creative Commons Public Domain Dedication waiver (http://creativecommons.org/publicdomain/zero/1.0/) applies to the data made available in this article, unless otherwise stated. 